\title{
Ecocritical Considerations of Nature in Contemporary British and Estonian Literature
}

\author{
MARIS SÕRMUS, JULIA TOFANTŠUK, SULIKO LIIV
}

\begin{abstract}
The issue of the environment has been never more topical than at present, with environmental problems being an urgent $21^{\text {st }}$ century concern. This topic, otherwise characteristic to natural sciences, has also found its way into literary studies in the form of ecocriticism, which affords an interesting insight into the representation of place and nature in literary texts. This article proposes to take an ecocritical stance, focusing on the aspect of nature in the work of contemporary British and Estonian writers, Graham Swift and Andrus Kivirähk; of special interest is the representation of nature, nature-culture interactions, and a possibility of a new way for seeing the world, that is, through the eyes of nonhumans. It is the nonhuman beings and green environment that constitute a presence in the novels and suggest questioning of such debate-spurning issues as anthropocentrism, nature's voice(lessness) and agency. Challenging established ideas of humanism and directing attention to topical environmental issues, the contemporary novels highlight a unique ecocentric direction in literature.
\end{abstract}

Keywords: ecocriticism, nature in literature, bioregionalism, contemporary Estonian and British literature

DOI: http://dx.doi.org/10.12697/IL.2013.18.1.08

\section{Introduction}

In the current paper we shall try to explore the issue of nature as portrayed in the work of Swift and Kivirähk, the highly canonical mainstream writers of the respective cultures. Taking as a ground of comparison Swift's Tomorrow (2007) and Kivirähk's Mees, kes teadis ussisõnu (The Man Who Spoke Snakish, 2007), a fresh look is applied to the novels by setting them into an ecocritical framework. We are interested in the representation and significance of nature: for instance, is it portrayed as a vital presence and subject of its own or an inferior object; is nature attributed with speaking ability? How is nature-culture relationship manifested? The article aims at demonstrating the meaningfulness 
Ecocritical Considerations of Nature in Contemporary British and Estonian Literature

of nature in the novels and the fact that it is not just a scenic backdrop or present merely for the sake of local colour.

The output of both Swift and Kivirähk is characterised by the use of allusions, word play, and breaking of literary conventions. Particularly, Swift's production is noteworthy for its strong sense of place, having been remarked to be one of the most important present-day chroniclers of landscape (Swift 1996: 299). Considering the latter and the fact that the environment (natural or built) is not a well-researched trait of Kivirähk's works, it is especially challenging to study the aspect, though not so obvious at first glance. On the plot level, the two novels are significantly different. Set in the twenty-first century, Tomorrow recounts the story told by the protagonist Paula, a mother of twins, as she lies awake in bed and uncovers in flashbacks and narrative jumps gradually the family secret. In contrast, Mees, kes teadis ussisõnu looks back at the times of the crusades and portrays the vanishing of forest life in Estonia and the invasion of new trends, causing the majority to move to the village. In and between these worlds, the protagonist, the last man who knows "snakish", the language of snakes, searches for his place, identity, and happiness. Moreover, Mees, kes teadis ussisõnu, which has been extensively analysed from the aspect of disappearing Estonian language, culture, and identity, has yet been pointed out as "the first Estonian eco-novel" (Hasselblatt 2007: 1262). Though with the novel a powerful green movement is said to have arisen in Estonia (ib.), the book has not been explored from this angle.

The current article attempts to analyse also Kivirähk's novel from an ecological perspective, as the natural environment is, indeed, a significant, uniquely portrayed presence in the book. The problem of the article, then, consists in establishing the representation and role of nature in the novels, assuming it to be a noteworthy presence. In what follows, first, an ecocritical framework is provided, and, second, the presentation of nature, ecological issues, as well as parallels and relations between nature and culture as manifested in the literary texts are to be explored.

1 The term has been provided by Jürgen Rooste on the website of Estonian Literature Centre, when introducing the novel. 
SÕRMUS, TOFANTŠUK, LIIV

Interrelations of literature and the environment in present-day criticism

Ecocriticism takes as its premise nature and culture, ${ }^{2}$ the nonhuman and the human, especially, the idea that culture is connected to the physical world, affecting it and affected by it (Glotfelty 1996: xviii-xix). A basis for environmentalist thinking is the persistence of place, nonhuman nature, culture's co-existence with nature, and giving voice to marginalised aspects of life. Importantly, a leading ecocritic Lawrence Buell has summarised an environmentally oriented work as non-anthropocentric, ${ }^{3}$ listing four distinctive features:

The nonhuman environment is present not merely as a framing device but as a presence that begins to suggest that human history is implicated in natural history [emphasis added];

The human interest is not understood to be the only legitimate interest;

Human accountability to the environment is part of the text's ethical orientation;

Some sense of the environment as a process rather than as a constant or a given is at least implicit in the text. (Quoted in Garrard 2004: 53)

In this discourse of the human/environmental, a specific way of referring to anthropocentrism and biocentrism has emerged, as proposed by Lawrence Buell: "humankind-first ethics" and "ecosystem-first ethics" (Buell 2003: 227) or, as proposed by Christopher Manes, "second nature" and "first nature" (Manes 1996: 23). Both concepts are instrumental in our study. In addition to the above-mentioned presence of nature and nonhuman interests, among the aspects that engage scholars across the area of ecocriticism is especially the question of nature's agency and voice. For years, the debate has been waging: does nature have agency? What counts as speech? (see e.g. Abram 2007,

2 In the current paper, culture is thought of in terms of the human (world, civilization), different from the nonhuman and the Earth (nature). For a definition of nature, see, for example, Kate Soper on 'The Idea of Nature', where she distinguishes between nature as a metaphysical (the nonhuman), realist (processes in the physical world), and lay or surface (landscape, countryside) concept (Soper 2000: 125).

3 Ursula Heise, who has proposed focusing on a sense of planet instead of the usual ecocritical focus on the local place, has termed ecological storytelling respectively "econarrative" (Heise 2004: 129), where the anthropocentric viewpoint is particularly experimented with by adopting a nonhuman narrator and providing thus an alien perspective. 
Huggan and Tiffin 2010). According to Christopher Manes, "nature is silent in our culture [as] [...] the status of being a speaking subject is jealously guarded as an exclusively human prerogative" (Manes 1996: 15). Nature is not a privileged voice, then, but tends to be regarded as silent, just as the voices of women, minorities, and children have been. In other words, nature tends to be viewed as the Other, silent and inferior to humans. ${ }^{4}$ Another ecocritic Scott Russell Sanders (1996: 194) has pertinently observed that though we are part of nature - we are dependent on the planet for food, energy, etc., and our bodies decay - it has only become an intellectual, not an emotional commonplace. One could thus generalise and ask: can nature speak at all? If usually nature is anthropocentrically spoken for (via environmental congresses, demonstrations, and protocols), then the loud environmental concerns and catastrophes, such as earthquakes, floods, and tornadoes, we could claim, suggest that nature still speaks for itself, at least metaphorically.

Furthermore, a critical stance is assumed towards hierarchies, in which nature tends to be eclipsed, pushed into an inferior background, and subjected to human needs. In contrast to anthropocentrism, ecocriticism recognises biocentrism, the nonhuman world as an equal subject of its own. Attempts are made to transcend the nature-culture duality by including, first, biocentrism, nature as a voice of its own, ${ }^{5}$ considering the fact that there are many other species besides humans and the voices of birds, animals, and natural phenomena. Nature is, then, tried to be raised from the position of the excluded Other to a 'self-articulating subject' (Oppermann 1999: 4). Hierarchical relations are crossed, secondly, by understanding that both the human and the nonhuman form the unity of life: significance is therefore attributed to contextualism and interrelatedness. The unity and co-presence of nature and culture have been termed 'postmodern' or 'third wave ecocriticism', distinguishable for its postmodern turn, with emphasis on multiplicity, heterogeneity, contextuality, and subversions of master narratives (Oppermann 2010: 19-20). Such a combination stresses movement from the idea of authority to that or relationality (ib.). Further support to the aspect of nature-culture mutuality has been amply

4 Parallels can be drawn with the issue of identity construction (see Tofantšuk 2007): by identifying an entity against a norm, the compared entity emerges as the Other, for it is different and does not conform to the norm.

5 The term biocentrism is obviously still hierarchical but it is commonly used to refer to the significance of nature. A step further in transcending nature-culture dichotomy is understanding their equality. The centredness around culture or nature could be crossed via the notion of bioregionalism (to be discussed in the final section) or Aldo Leopold's concept of 'land ethic' - in their emphasis on the fact that the parts of the community (human and nonhuman) living on Earth are interdependent. 
SÕRMUS, TOFANTŠUK, LIIV

provided by William Rueckert, whose statement "everything is connected to everything else" has been even established as the "the first Law of Ecology" (Rueckert 1996: 108).

It is this dialectics of nature-culture interaction, hierarchies, biocentrism and anthropocentrism, plurality of voices and subjects that we shall now explore in the framework of Swift's and Kivirähk's novels.

\section{The visibility and vitality of nature in Tomorrow and Mees, kes teadis ussisõnu}

Nature forms a unique meaningful presence in both novels. Its significance lies not only on the level of representation, but pertains to the overall conflict and problematics of the novels.

More specifically, Mees, kes teadis ussisõnu portrays the vanishing of forest life and the invasion of new trends, whereas the protagonist is the last to dwell in the forest and speak the ancient snake language. The village people begin to approach their previous forest-home as a wild place, that of animals and savages. The protagonist has nothing but to admit:

The world itself changed around me. Metaphorically said: there, where dry land used to be, surged now the sea, and I had not managed to grow myself gills; I still gasped for breath with my old lungs, which didn't pass for anything in the new world, and that is why I constantly lacked air. I tried to escape the approaching water and dig myself a nest in the sand, but each subsequent wave thwarted my efforts until there was neither a nest nor a shore. (Kivirähk 2010: $316)^{6}$

Here, the forest emerges as a self-contained super-character that spreads out and takes over the abandoned roads and houses. The protagonist Leemet observes that the forest has become "a thing in itself, which lives its own life and breathes in its own rhythm” (ib. 141), illustrating nature's powerful presence and self-regulation; furthermore, the environment in process allows it to be seen in terms of Buell's typology of an eco-novel. The forest is juxtaposed interestingly to the Northern Frog, the ancient snake-like giant who is able to eclipse the whole sun and moon (ib. 9) and whose hidden presence becomes

${ }^{6}$ Here and in the following the translation of quotations from Kivirähk's novel are ours. M. S., J. T., S. L. 
Ecocritical Considerations of Nature in Contemporary British and Estonian Literature

symbolic of nature: being there, yet not recognised by the villagers. Also significant is the prevailing image of water, which appears to convey the loss and emptiness.

In Tomorrow, juxtaposition and the idea of boundary similarly add to the overall conflict of the novel. Rain, forming a strong presence throughout the novel, functions as one of such boundaries. It is also raining when the protagonist Paula tells her bedtime story. She notes that "tomorrow this house will be curtained and cordoned off by a veil of rain" (Swift 2007: 9). Thus, rain is about to separate the family secret that Paula is to hide from other ears. A similar protective function appears during the funeral of Paula's father, when the woman is screened by rain, which is further noted to be superior to bagpipe sound (ib. $72,121)$, highlighting hence the very presence of nature. Most significantly, rain is said to be a guardian, "pressing a finger to its lips: Sssshhhh..." (ib. 154) the personification makes it proper to be compared to an alive being, like a participant, who guards the family and the secret.

Another important presence in the novel is the living world. Paula's husband Mike namely runs the respective journal The Living World. His devotion to it, just as the very phrase "living world", is symbolic demonstrating that the nonhuman nature is also alive, a living being, as real as human beings. However, Mike's close relationship to the living world suggests not only biocentrism but, even more, a unity of the human and the nonhuman. The Yin-and-Yang biosphere logo of the journal (ib. 95) seems also symbolic of the unitary interrelations. Paula's admitting of the fact that she and Mike had no children but the Living World seems also to suggest why it is as noteworthy as it is. The fact that The Living World is run from an attic in Bloomsbury (ib. 93) and Mike's research is done at the labs at Imperial (ib. 55) vividly illustrates the general yet usually not admitted truth of the living world being above other factors in life, in many respects. Also, Paula's decision for artificial insemination on the grounds that continuation of life seems more important than social ties is rather similar to snake Ints' observation about coupling in the natural world: it is not about love but finding somebody suitable for producing offspring ( $\mathrm{Ki}$ virähk 2010: 157).

The living world, however, appears also vividly from a very different perspective: in the state of apocalyptic perishing. In other words, Mike has remarked that the magazine ought to be called in fact The Perishing World, for the reason that "more and more of its pages seem to deal with declines and depletions, not to say outright extinctions, things going wrong with nature, harm being done to it, disasters in store" (Swift 2007: 225). Indeed, the environment is obviously a global, urgent concern in the present-day world, with various natural catastrophes and global issues. Mike, more specifically, worries about 
"the 'just nature' books" (ib. 226): beautifully coloured, nice to look at, and about just animals. He is right to be concerned that approaching nature as just something turns out to be "heads-in-the-sand stuff" (ib.): a careless attitude, not wanting to see or admit the effects on the environment. As it is emphasised already through the image of the perishing world, the warnings are not taken from the air, but the planet is in trouble (ib.): nature is, or at least should be, much more than just nature - the very concern itself, in need of serious attention. In the ample summary of ecocritic Sanders: "If we are to survive, we must look outward [...] to the stupendous theatre where our tiny, brief play goes on" (Sanders 1996: 195).

Drawing on the motif of the perishing world, Swift approaches interestingly the issue of Noah's Ark. The biblical story appears namely through a local angle, the twins' paintings of Noah's Ark. The children are stuck especially by the fact of animals going onto the ark two by two in order for the world to be saved (Swift 2007: 229). The biblical flood implies not only the world to be saved, but there is an interesting extra dimension on the local level. That is, the fact that rain appears on the paintings too and the box, containing the drawings, is said to liken a miniature ark, waiting for a rainy day (ib. 228, 230), explains the importance of rain in the novel: it is the family life to be saved, too, when the truth about the twins' father is revealed.

We could thus generalise and say that in addition to the presence of nonhuman concerns the novel implies an ethical orientation and the fact that there are other interests apart from the human ones, illustrating the work as environmentally oriented. So appears to be also Kivirähk's novel, in which the perishing (natural) world is highly present, too. Most obviously, the dominant motif of being the last forest dweller and the man who knows the language of snakes does foreground the theme of extinction. On a more general level, the forestvillage or nature-culture dichotomy becomes representative of the presentday countryside-city dialectics in Estonia. The tendency of the forest dwellers to move away from nature into the modern environment represents the trend in present-day Estonia of more and more people choosing life in bigger towns. The countryside as a result becomes, or, in fact, is the periphery, not very far from an empty place, or mostly the place of the older generation. ${ }^{7}$ Moreover, like Rome serves in the novel as a centre contrary to the village/periphery, in reality, the cities of Estonia too could be seen as a periphery - for a number of

The novel highlights some of the contemporary problematic concerning life in the countryside, such as encapsulation, contrary to the logically expected solidarity and uniting in the face of danger (see the examples on Tambet on pp. 83, 152), ignorance and drinking (see p. 107 where Meeme admits the pleasurable sleepiness). 
Ecocritical Considerations of Nature in Contemporary British and Estonian Literature

Estonians tend to leave for foreign countries, away not only from the countryside but even from the very fatherland.

Thus, the idea of boundary communicated through nature is strongly present in both novels.

Nonhuman creatures, voices (un)heard, and nature-culture relations in Tomorrow and Mees, kes teadis ussisonnu

The nonhuman images occurring frequently in both novels and therefore acquiring instrumental value are snails and snakes. Mike in Tomorrow is namely a devoted researcher of snails. He is interested in the peculiarity of things and finds extraordinary in the seemingly unimportant ordinary, especially the natural world. By doing so, he exemplifies well unitary interrelations between nature and culture as well as pleasure in the living world. For the present-day children, however, as Paula remarks, nature seems to be history: "They don't ask for the world, do they, they don't even want it" (Swift 2007: 81); for children, villages, country cottages, and even the country itself appear to belong to an old-fashioned picture-book (ib.).

Mike is nevertheless attracted to molluscs - which, according to him, form "the very composition of the world" (ib. 18). Snail shells and fossils in general form understandably the ground of life, and so Mike also notes that without the shells there would not be any South Downs (ib.), an important place in the couple's personal history. Paula's summary of Mike's research field is particularly suggestive:

His special field, as you know, was molluscs, and within that special field, his special area was snails. And his special area within that special area, which he would say wasn't at all small, was the construction and significance, the whole evolutionary and ecological import, of their shells. (Ib. 17-18)

What strikes the eye in this quotation is, first, the specific way of presenting it: resembling the form of a spiral or a concentric circle. ${ }^{8}$ And this seems to be not a coincidence, for snail shells also form a spiral, delving deeper inwards. What is also unique about the snails is that with the shell snails carry their home on

8 The spiral form is generally significant from the stance of ecocriticism, too. The logo of the European association of ecocriticism, EASLCE, is a spiral, said to bridge the gap between nature and culture. See www.easlce.eu. 
their back: though nonhumans they also dwell. Second, the shells create a sense of security; the robes and authority of the judge Dougie, Paula's father, are said to be his shell that no one can take from him (ib. 63). Further, on the basis of the shells, snails and limpets - whose shells are not spirally coiled - are differentiated (ib.18), becoming parallel to adults and children. Snails' spiralling shells are likely to echo the complexities of adult life, whereas for the children the spirals/problems have not yet emerged. Last but not least, Paula's remark that she is interested in her family's future, not the world's (ib. 225), seems to be very much the attitude, people living in their own shells, that brings about the global ecological crisis.

The motif of snails occurs also interestingly in Mees, kes teadis ussisõnu. Let us consider Leemet's comment on Johannes and himself as a particularly cogent illustration:

We lived in different worlds like two snails who don't manage to take a glance in each other's shells. Even if I told him that in my shell there are snake words and the Northern Frog, he wouldn't believe me, because he thought of seeing God and the Roman pope in his shell. (Kivirähk 2010: 170-171)

In other words, the characters retreat stubbornly inside their own shells, respective worlds and stick with their identity. The traumatic clashes, as there are many more of these, become vividly parallel to the spirals of the snail shells.

Another interesting informative structure in the novels is that of cycles. Mike, namely, tells Paula about natural history and the life cycle of snails; the work on snails is also said to entail long-term cycles of experiment, not sudden discoveries (Swift 2007: 57). In Kivirähk's novel, on the other hand, Vootele, for instance, compares leaving to waves: for several years no one leaves, while suddenly many families go, followed by others (Kivirähk 2010: 119). There are cycles in terms of ending up in the place one has been to (see e.g. 354, 357); Leemet, more specifically, when going forwards is said to go backwards too (ib. 354), implying disorientation, not identifying with the modern world. Overall, the presence of cycles, shells, and spirals both in real life and nature indicate parallels between the human and the nonhuman (life).

Turning to the presence of snakes in Mees, kes teadis ussisõnu, the animals' individuality lies in being a self-articulating voice and agent. They are presented as one-time brothers of humans with whom a common language is spoken. The last to speak the animal language is Leemet, who also represents a symbiotic relationship of the human and the nonhuman, developing a life-long friendship with the snake Ints. The unique co-presence manifests itself clearly 
Ecocritical Considerations of Nature in Contemporary British and Estonian Literature

when Leemet congratulates Ints on her new-born offspring, and the snake licks the boy's face (ib. 159). However, when Leemet mistakes Ints for a male animal, an inevitable difference between nature and culture is presented, just as the implication of nature having its own secrets. This episode also casts light on the place of gender in nature and in culture: Leemet, who used to consider Ints male, now learns that she is female; however, the change of gender occurs only on the verbal level and does not affect the harmony of their friendship in any way. Thus, gender with its necessary attributes emerges as a culturally constructed phenomenon, which does not bear significance in forest life.

Contrary to the above-illustrated unity, the villagers regard nature hierarchically as inferior satanic being (see e.g. 162, 166). When moving to the village, the characters adopt the axiology of the outside world, including Christian beliefs, therefore understandably seeing God to be above nature. Drawing from Christianity - the all-powerful God creating nature and putting man in control of it as well as naming it - the villagers' anthropocentric stance is understandable. The villagers become distanced from nature, contending that "snakes do not matter" (ib. 125); what matter is the foreign countries beyond the seas and the magnificent churches there, so high that no spruce here reaches them (ib. 125, 169). Even further, the villagers start denying the snake language that they themselves once spoke. Johannes, among others, contends that there are no such words:

How else could it be that the church knows nothing about them? [...] Even if there were snake words, the pope and the other holy men would understand them, but there are no such words, as God has not given snakes the ability to speak. They should not be spoken with but they have to be killed, that is, frightened off with prayer [...]. (Ib. 169)

Johannes' utterance is a vivid example of an anthropocentric monologue, insisting on nature having no voice. Precisely the stark centredness around (Christian) culture, setting of God above others and nature having not been given a speaking status, strengthens the dichotomy in which nature tends to be regarded as the (mute) Other.

In the naturalisation of the worldview and the culture-nature clash, the village becomes, then, so alienated from the forest that the latter is imagined as a hostile place, attributed with stories about werewolves and fairies (ib. 175, 179). Thus, one could say that in losing the connection with nature, the villagers start losing partly their own naturalness. As the snake language is spoken and the denied Northern Frog also exists, nature is only presented as inferior. 
The villagers' superiority is only seemingly so, considering, for instance, the fact that the characters are bitten by snakes and die not knowing the ancient world's language. Nature is after all a powerful, even superior, presence: many characters survive thanks to the language (see 212,140); already one correctly pronounced snake word can help save a life or kill a being. What adds to nature's presence, making it even more vivid, as well as complicated, is that inside nature there also are oppositions. Snakes more specifically regard animals that cannot speak snake language as inferior: hedgehogs on the one hand are termed blockheads, as stupid as cones (ib. 34), ants on the other as rubbish, like villagers living in a cluster (ib. 126).

However, more important than all the animals speaking necessarily the same language is the fact that they do speak: they have their own voice, distinct and powerful. In other words, they speak directly, not metaphorically, emerging thus as alive beings, characters of their own - consequently, in their direct speaking ability even more present than, for instance, the personified rain of Tomorrow. The unusual voicing of nature in Kivirähk's work and its portrayal as a self-articulating subject, even superior to humans, seem to have a defamiliarising effect so that nature is seen and heard - not regarded almost automatically as a scenic backdrop or a descriptive passage. Finally, the dominance of the snakes themselves is to be noted, for they are strikingly similar to the snails in Swift's novel: both focus on slippery creatures, something that tend to be often regarded as repulsive molluscs.

Why, then, has such an extraordinary focus been chosen? Besides bringing to the fore nature, the nonhuman that tends to be otherwise approached as silent, the slipperiness seems illustrative of the fact that there is usually no single truth or vision but a plurality of possibilities. In Kivirähk's novel, the forest dwellers have their old-world beliefs, while the villagers have yet other beliefs. In Swift's work, Paula and Mike are attached to nature, while for another generation this might already be history. Generally, then, the slipperiness could suggest hybridity, rhizomic intertwining of nature and culture. Interesting is also the animals' form: like the spiral, cyclical structure of the snail shells, the snakes also set themselves into a circle. The starting and ending point meeting in a circle seems to illuminate well the relatedness of nature and culture - indeed, the protagonists keen on respectively snails and snakes do represent the unity of the human and the nonhuman. 
Ecocritical Considerations of Nature in Contemporary British and Estonian Literature

\section{The human and the nonhuman nature. Bioregionalism}

Both narratives represent the human world as close to that of the nonhuman, the latter functioning as a vivid parallel level to the human action. To adduce an instance, in Tomorrow it is the pearly clouds, approving sun, and gold deepening light that welcomes Mike and Paula the next day after their love experience (Swift 2007: 29, 44, 48). Paula also wonders on the perfection of the moment:

He'd [Mike] planned the weather? He'd planned that the tide would be so co-operatively full and then - but it's only what tides do - slowly, respectfully creep away? That the afternoon would turn gold and dreamy, and that as the light deepened and the tide slipped further out, Linda and Judy [the couple's friends] [...] would get up and slip away too, guests at our feast who knew nonetheless when they ought to be going? (Ib. 48)

Indeed, these details of nature are not accidental but highlight the significance of the particular moment for Paula and Mike. It is their private moment, together; not only other people but also the tide is said to creep away - respectfully.

Yet another interesting example is the marriage proposal at Craiginish, when before the significant moment Mike talks about marram grass growing on the dunes and compares it to limpets. The fact that the grass clings to and takes root "where no other plant will, on bare and barren sand" (ib. 77) seems to be a parallel to Mike and Paula themselves: just as they are close to the spot, they are clinging to each other, taking root in each other's heart even more strongly. What is more, their union is going to be barren, the essence of the family secret being that they cannot have children in the natural way. The presence of the grass is also evident in its waving and whispering (ib.) - the personification suggesting the nonhuman world to be alive and an active participant in the moment, reflecting the characters' whisperings and emotions.

In Mees, kes teadis ussisõnu, in turn, the green, mostly in the form of trees, provides a parallel dimension to human events. Leemet, for instance, senses the broken-off and dried branches of trees to be related to the leaving. The feeling as if a hole had been made into the forest, emitting something alien and unpleasant into the place (Kivirähk 2010: 118) becomes symbolic of the presence of the outside, which is powerfully pressing into the inside of the forest. To escape from the alien culture, the human apes retreat into nature, a truly biocentric home - the tree tops: "They wanted to go as far back to the past as possible, for they believed that only the ancestors knew the truth and all the subsequent 
SÕRMUS, TOFANTŠUK, LIIV

development was only an uninhibited falling into a swamp [...] secure ground was a branch of tree under the naked bottom" (ib. 154). It is, then, in the far depths of nature that the apes find their history and a sense of belonging.

Drawing from the latter, the human and the nonhuman are even more interestingly related, for what contributes to the uniqueness of Kivirähk's (therefore eco)novel is the portrayal of human history in line with that of the natural. Let us next explore the unusual aspect further. Leemet's sister Salme is a particularly illustrative instance here: like the forest starts to turn into bush, Salme retreats into a bear's den, which looks more like a wild place than a human dwelling (ib. 364). Furthermore, Salme herself, eating raw meat and her hair as well as her overall appearance looking dishevelled, is observed to be closer to a bear than being a human. Leemet, however, does also resemble the decaying forest, "being exactly the same moulded piece of a meat, who tried to intensely retain the former freshness and imagine that he still passes for something" (ib. 366).

Another significant similarity is the decaying of the forest in line with the discarding of the place. Meeme, in particular, observes the forest dwellers to be like tree blades from the previous year, brown and decayed; the new green buds and the whole new life on the tree (ib. 195) at the same time represent the villagers. The humans leaving the forest are further compared to the birds leaving for the South: some immediately, some later. Vootele observes that he and his family are like crows and owls, which stay for the winter as well (ib. 119). After all, Leemet does leave too and his life shatters after the actions of the grove keeper. The ensuing collapse is illuminated by the natural history of the forest, through rotted trees, which fall down with a crash and leave a hole in the forest (ib. 334). Rather similarly, the wrong goings of Leemet's life are parallel to:

[...] a bird, who builds itself a nest high up in the branches, but at the same moment when it sits on eggs the tree falls down. The bird flies to another tree, tries once again, lays eggs, incubates, but on the same day when the chicken hatch out, a storm starts and this tree, too, cracks into pieces. (Ib. 316)

The recurrent image of trees, then, becomes symbolic of the decaying forest but serves also as a vivid parallel to human history - to the shattering of Leemet's life, of his place, of all the meaningful.

A step further from the human-nonhuman parallels is approaching them as a whole, interrelated and inclusive. Herein, one could consider a rather new concern on the place-scale, that of bioregionalism. The term, originating from 1970s' US, refers, first, to a geographical terrain with its own physiography, 
Ecocritical Considerations of Nature in Contemporary British and Estonian Literature

climate, watershed, animals, and plants, being either rural or urban (Buell 2005: 83, 88). Second, it is understood as a "terrain of consciousness" (ib. 83); in Buell's hope, bioregion may come to substitute "a nationalist vision of the globe and of interstate relations" (ib. 82). Bioregionalists namely criticise nation-state borders and suggest the biological region instead of national and political divisions. Bioregion, then, as a terrain of consciousness is a specific view to the world, which instead of restrictive boundaries views them as one inclusive community.

It is this alternative bioregional ethics with emphasis on the ecosystem as a whole, comprising both the human and the nonhuman that casts particularly pertinent light on Kivirähk's novel with all its hierarchies. Namely, in spite of the clash between nature and culture in the novel, they still form constituent parts, dependent on each other. That is, the village still returns to the forest directly or indirectly by way of subversions, and is not only affecting nature (the extinction) but is also affected by it (a war is started from the side of the forest). The formation of a bioregional whole is evident already with the anthropoid apes mentioned above, who in their earth-centredness merge with the environment, not only retreating into the trees but forming a balanced co-presence with the lice, which they breed. Thus, the apes themselves are an illustration of the human-nonhuman unity.

Meeme, however, demonstrates even more significantly the nature-culture relatedness: he has no house but is found close to the ground, like a blade of a tree (Kivirähk 2010: 10). Symbolically, with his moss-covered clothes and a beard holding insects and plants, he is said to liken "human turf" (ib. 153). Similarly to Meeme's wish to rot in the place where he dies (ib. 263), he finally merges with the earth and dissolves in it (ib. 374). As it is not possible to tell "where his body ended, and the moss began" (ib.), Meeme demonstrates succinctly the porous boundary between the human body and the nonhuman nature. The merging with nature is further manifested through Leemet, who dwells finally in the Northern Frog's cave; the boy's mother, who dies together with the snakes in their cave; the grandfather, who crawls in his island's grass like a snake and whose head rolls into sand when cut off by a knight and mixes with it; and Leemet's sister, who retreats finally into the bear's den. As it turns out, in addition to the parallels between nature and culture, Mees, kes teadis ussisõnu is particularly illustrative of the bioregional whole, suggesting an alternative way for crossing hierarchical differences. 
SÕRMUS, TOFANTŠUK, LIIV

\section{Conclusion}

In this article, we have taken an ecocritical look at contemporary novels by Graham Swift and Andrus Kivirähk by considering the issue of nature in their texts. The natural environment of the novels provides namely not just a framing device in the form of a setting but constitutes a presence of great communicative value. If in Mees, kes teadis ussisõnu the forest emerges as a self-contained presence, in process, then the living world and rain of Tomorrow suggest nature as a living being, with a character of its own; the rain functions as a boundary and juxtaposition to the human world, as well as communicates the idea of perishing. In Buell's terminology, these novels therefore emerge to a great extent as environmentally oriented, displaying also topical environmental issues, an ethical orientation, and, with reference to Mees, kes teadis ussisõnu, the implication of human history being parallel to natural history.

The novels are further characterised by an unusually powerful focus on nonhumans: snakes and snails, through which both protagonists demonstrate nature-culture interrelatedness. Swift shows extraordinary as being present in the ordinary snail shells, which, however, form the very ground of life. Differently from the personified rain and grass of Tomorrow, Mees, kes teadis ussisõnu portrays nonhumans as a direct self-articulating voice. Kivirähk's novel challenges further the hierarchical view of nature as the inferior and mute Other, making it a voiced presence that, through such a portrayal, seems to have the effect of being heard and noticed. Drawing on the hierarchical relations, the environment of this novel could be well approached as one inclusive bioregional whole, suggesting an alternative ethics and care.

Therefore, nature is portrayed in the novels as a meaningful presence that communicates (1) the general concerns of the novels (saving the family life and the world from perishing vs. loss and emptiness), (2) the idea of a boundary, (3) clashes and conflicts (via the spiralled shells), and (4) nature-culture relatedness (via the structure of cycles). The significance of nature lies also in functioning as a parallel level to human action and emotions. We may claim that the two major contemporary writers are adopting the topical 'ecosystem-first' ethics, thus indicating a new direction in literature, both English and Estonian.

Maris Sõrmus
maris.sormus@tlu.ee
Tallinna Ülikool
Narva mnt 25
10120 Tallinn
EESTI

Maris Sõrmus

Julia Tofantšuk

jul@tlu.ee

Tallinna Ülikool

Narva mnt 25

10120 Tallinn

EESTI

\author{
Suliko Liiv \\ liiv@tlu.ee \\ Tallinna Ülikool \\ Narva mnt 25 \\ 10120 Tallinn \\ EESTI
}


Ecocritical Considerations of Nature in Contemporary British and Estonian Literature

\section{References}

Abram, D. 2007. The Spell of the Sensuous: Perception and Language in a More-thanHuman World. New York: Vintage.

Buell, L. 2003. Writing for an Endangered World: Literature, Culture, and the Environment in the U.S. and Beyond. Cambridge, MA: Belknap of Harvard University Press.

Buell, L. 2005. The Future of Environmental Criticism: Environmental Crisis and Literary Imagination. Oxford: Blackwell Publishers.

Garrard, G. 2004. Ecocriticism. London: Routledge.

Glotfelty, C. 1996. Introduction: Literary Studies in an Age of Environmental Crisis. - C. Glotfelty and H. Fromm, eds., The Ecocriticism Reader: Landmarks in Literary Ecology. Athens: University of Georgia Press, xv-xxxvii.

Hasselblatt, C. 2007. Eesti esimene ökoromaan. - Looming, 8, 1262-1267.

Heise, U. K. 2004. Eco-Narrative. - D. Herman, M. Jahn, and M-L. Ryan, eds., Routledge Encyclopedia of Narrative Theory. London: Routledge, 129.

Huggan, G. and H. Tiffin. 2010. Postcolonial Ecocriticism: Literature, Animals, Environment. London and New York: Routledge.

Kivirähk, A. 2010. Mees, kes teadis ussisõnu. Tallinn: Eesti Keele Sihtasutus.

Manes, C. 1996. Nature and Silence. - C. Glotfelty and H. Fromm, eds., The Ecocriticism Reader: Landmarks in Literary Ecology. Athens: University of Georgia Press, 15-29.

Oppermann, S. 1999. Ecocriticism: Natural World in the Literary Viewfinder. - The Association for the Study of Literature and Environment, http:/www.asle.org/assets/docs/oppermann.pdf (31.07.2012).

Oppermann, S. 2010. The Rhizomatic Trajectory of Ecocriticism. - Ecozon@, 1.1, 17-21, http://www.ecozona.eu/index.php/journal/article/view/22/66 (31.07.2012).

Rueckert, W. 1996. Literature and Ecology: An Experiment in Ecocriticism. - C. Glotfelty and H. Fromm, eds., The Ecocriticism Reader: Landmarks in Literary Ecology. Athens: University of Georgia Press, 105-123.

Sanders, S. R. 1996. Speaking a Word for Nature. - C. Glotfelty and H. Fromm, eds., The Ecocriticism Reader: Landmarks in Literary Ecology. Athens: University of Georgia Press, 182-195.

Soper, K. 2000. The Idea of Nature. - L. Coupe, ed., The Green Studies Reader: From Romanticism to Ecocriticism. London: Routledge, 123-126.

Swift, G. 1996. Last Orders. London: Picador.

Swift, G. 2007. Tomorrow. London: Picador.

Tofantšuk, J. 2007. Construction of Identity in the Fiction of Contemporary British Women Writers (Jeanette Winterson, Meera Syal, and Eva Figes). Tallinn: TLÜ Kirjastus. 